\title{
A Review on Decision Processes for Wood Harvesting in Turkish Forestry
}

\author{
Mehmet Eker \\ Isparta University of Applied Sciences, Faculty of Forestry, 32260, Isparta, Turkey
}

\begin{abstract}
This review article provides an overview of decision-making processes for harvesting of wood based forest products, which should include criteria that are environmentally friendly, technically feasible, economically viable, socially and institutionally acceptable. The decision-making on wood harvesting is a complex task that requires supporting management strategies for, not only satisfy socio-economic expectations but also handle environmental considerations. The changing paradigms and developing technologies related to forestry have a significantly impact on the contents of the decisions. In order to measure and evaluate the effectiveness of the decisions, it is necessary to analyze the issues taken into consideration and focused in decision making processes. The aim of the article was to demonstrate the state-of-the-art of the decision making processes in Turkish forestry and review the contents of decisions in terms of adaptation to changing forestry operations management and technologies. Depending on the current status, the decision process related to wood harvesting system was firstly divided into two sub-process as managerial (administrative) and operational (technical), and then, each process was separately analyzed. To analyze managerial process in forest administrations, it was used a job analysis method by following of hierarchical and ordinary the paper-work procedure. For analysis of operational process, process mapping and work flowcharts were used by means of work study methods belonging to previous researches. It was found that the decisions were economical oriented (budget balanced) and societal sophisticated in administrative process. In the operational step, the harvest operations were based on technical and economic completion with basic and to moderate technologies. Environmental issues were not completely prioritized as a primary subject in any of the decision-making processes, yet.
\end{abstract}

Keywords: Wood harvesting, Managerial process, Operational decisions, Decision-making process, Job analysis method, Turkish forestry

\section{Introduction}

The perspective on forests and forestry is shaped and evolved according to the requirements of the time. The increasing importance of forests for humans, ecosystems and the universe changes the theoretical and practical understanding of forestry of individuals and communities. People's attitudes and expectations highlights different aspects or functions of forests and changes in various dimensions in forestry objectives, policies, strategies and management. Accordingly, the understanding of forestry (paradigms and practices) also changes and progresses relatively (Eker and Çoban, 2017). Traditional public paradigms and approaches about utilization and protection of forest resources have speedy changed worldwide. Today, sustainability of forest resources as economical, ecological, and social aspects is the basically widespread principle in forestry. Additionally, wood harvesting for wood supply is one of the main utilization types on account of sustainable forest management criteria.
Population growth rate, income level, urbanization, industrialization, increase in education level, improvements in infrastructure facilities are the main effects that cause societies to undergo economic, social, cultural, technological and political changes (Türker et al., 2001). Besides the problems and needs experienced in various issues such as global climate change, deforestation, environmental pollution, biodiversity loss, water and nutritional needs, rural development and forest products production, other functions offered by the forest ecosystem and people's expectations are diversifying and changing shape. However, although product and service demands and supply differ in time in terms of quality and quantity, it can be said that they are still continuing without slowing down. In this context, the establishment of the infrastructure that will provide physical access to forest resources and, ultimately, forest harvest operations continue to be the focus of interest both economically and technically and also environmentally and socially. In 
this formation; positive and negative aspects of forestry operations such as wood harvesting and people's perspectives on these operations are effective.

It is obvious that the demands for wood products have been eternally continued and couldn't be suppressed by any substitution materials, yet. Therefore, taking of multi-dimensional precautions is necessary to remove conflicts and to reduce adverse impact of wood harvesting. The precautions that are mirror of the sustainability principles should be considered in decision-making process such as forest acts, policy, strategy, planning, and implementation process of harvesting. However, it is difficult task to insert and adapt the reformative strategically principles such as governmental rules (regulations and guidelines) and professional rules (code of practice, standards, Best Management Practices/BMPs) (Heinimann, 1999) to current harvesting systems.

Considering the forestry paradigms that evolve and change both in theory and in practice and displaying attitudes accordingly can be an important criterion or indicator in terms of measuring and evaluating forestry practices. Because of the decision makers who take charge in the planning, implementation and management stages; the fact that it displays environmentally and technologically sensitive attitudes and behaviors at forest, stand and tree scale proves that improvements have been achieved in this regard. Therefore, it is necessary to evaluate whether this environmental considerations and technological sensitivity resulting from changing paradigms is taken into consideration in the administrative and operational processes of wood production in also Turkish forestry.

In this study; an assessment has been made as to whether the decisions (with environmental considerations) and the principles attached to them within the framework of forestry objectives, policies and strategies can be inserted to wood production practices within the scope of the hierarchy of norms. This study aimed to explore the conceptual framework of the decision processes for wood harvesting system and to sketch a vision how wood harvest operations could look like at the current status of managerial and operational process in Turkish forestry having a transition economy. Additionally, it was also intended to discuss the major challenges that it will be probably been faced with. The scope of the article is somewhat limited by perceptions, expectations and attitudes of the author.

\section{Methodology}

The article is a part of the evaluation on lessons learnt related to the adaptation of sustainable forest management into forestry practices in Turkey. The study includes assessment of hierarchical norms related to wood harvesting, country reports and returns on the adoption and progress of sustainable forestry, analysis of previous field observations and results of previous studies. The scope of the study is focused on the wood harvesting process, called as wood procurement process or system, including organizational, technical, economical, societal, and environmental components.

To analyze the wood harvesting process, it was firstly charted the process map and then decided to be divided into two sub-process as decisional and operational, respectively (Eker, 2004). The decisional (sub)process is intensely administrative and organizational, and is mentioned in this paper as managerial process. To analyze managerial process where harvest decisions were being bureaucratically made in forest administrations from local to regional and national scale, it was used job analysis method based on induction procedure by following of the paper-work. At this stage, it was examined and evaluated that are (i) life cycle of harvesting decisions (how is decided to harvest a forest compartment), (ii) objectives of the harvesting operations, (iii) structure and outputs of the process, (iv) public participation to process, (v) whether or not any governmental and professional rules are used to provide ecological, economical and societal sustainability of forest harvesting decisions.

The operational (sub)process is the technical process based on work flow from stump to mill, comprising of felling, extraction, and hauling operations. To analyze the process, it was used direct observation technique (during other researches), part of well-known work study method, recorded work steps and tools and technique, used in through harvesting operations, and then modeled work flow diagrams. It was studied and evaluated that are: (i) how work step was to be enumerated, (ii) which harvesting technology was used or preferred, (iii) who responsible relevant to work and how was to be done work contract (iv) whether or not any guideline or code of practice was taken into consideration during the works.

In terms of the comprehensibility of the subject, firstly, the impacts of widespread forestry approaches were partly and briefly mentioned to the forestry operations for the writing of the article. Furthermore, the legislation/procedures governing the wood harvesting in Turkey and wood harvest operations were put forward taking into account the general condition of the process. Then, Turkey's administrative and operational scales of the decision-making process with different aspects were compared with the widespread approaches in changing world in order to discuss the subject and to compile the review. In this article, the findings obtained from the evaluation of all steps of each processes were not presented individually, but the general results were only given and discussed.

\subsection{Reflections of Forestry Approaches on Wood Harvesting}

It is an appropriate attitude to hierarchically consider people's perspectives on forests or their general approach and understanding of how they perceive and manage forests. On a strategic level (global scale), when we look 
at the people's approach to use forests; it seems to have various approaches such as full protection of the forest, imitating the functioning of the forest ecosystem (suitable for nature), changing the forest ecosystem to a certain extent without disturbing its balance (close to nature), and making changes suitable for human purposes in the forest /nature (for socio-economic purposes). At the basis of these approaches are two thoughts that contradict each other on a global scale: One of them is human centrism (is the idea that nature is valuable to the extent of its benefits to human), and the other is biocentrism (the thought that nature should be respected due to its own value). So in terms of the understanding of forestry; it is seen that there is a difference between the narrow understanding of forestry (biological origin; environmental protection sensitivity) and modern forestry understanding (comprehensive/ versatile and sensitive data-based information) (Eker and Çoban, 2017).

However, forestry approaches evolve from exploitation forestry to production forestry and then to multifunctional forestry. In terms of application type; nature-friendly forestry (continuous forest; forestry close to nature) has a tendency. At the tactical level, forest management, respectively evolves from continuous wood production, continuity of multi-purpose goods production, sustainable forest management and to ecosystem-based management approach.

Related to environmental considerations, Brundtland report (1987) presented forward the sustainable development concept (Paivinen and Lindner, 2006). In 1992, United Nations Conference on Environment and Development (UNCED-1992), proposed to philosophy of Sustainable Forest Management (SFM). As a following process, the Sustainable Development Board of United Nations set up inter-government program of forest, in 1995. In these actions, it was proposed activities, advices, and improvements on sustainable forest management containing wood harvesting. The pursuit of the sustainability of the wood harvesting comprises of environmental (biodiversity, soil fertility, water quality, carbon sequestration, energy efficiency, pollutants and wastes, etc.), societal (institutional, employment, market demands, cultural values, public involvement, rural development, human health, ergonomics, etc.), and economic dimensions (competitiveness, adding value, real income, investment, cost-benefit, energy use and production, etc.) (Paivinen and Lindner, 2006). The challenge was to balance between harvesting operations and natural process and systems (Heinimann, 1999).

IUFRO, which is an organization that prioritizes the production and sharing of scientific information for the protection and sustainability of forests, has accepted the forest operations as a science discipline. According to this, forestry operations science; characterizing the planning, organization, implementation, control and continuous development of forest operations such as wood harvesting is focused on both technology and problem solving methodology (IUFRO, 2017). At present, how forestry paradigms and technology change and shape harvest operations at the theoretical and practical scale remains a subject of much emphasis.

In the worldwide, some improvements in the planning, implementations, and inspection procedures, were provided for environmentally friendly, technically feasible, economically viable, and institutionally acceptable actions in order to be incorporated into forest harvesting operations and its decision process. In addition to technical feasibility and economical viability of wood harvest operations, public interest and consciousness have become more considerable for environmental soundness and institutional feasibility. Therefore, it has been primarily made some arrangements by means of governmental and professional rules, in the context for courses of action. It has been struggled how public participation is to be inserted in whole decision processes. Professional rules on environmental sensitivity, safety and health (ESH) for forest operations, such as international technical standards (ILO, 1998; Heinimann, 1999), code of practices (Dykstra and Heinrich, 1996), and guidelines (IFC, 2007) have been set up on a voluntary and/or obligatory basis. Additionally, forest certification systems have been developed to provide an independent assurance that the quality of management practiced by an enterprise conforms to specified standards. In this procedure, in the case of forests, the management of the forest is compared to a standard of good forestry practices.

For all that, mitigating environmental impacts of wood harvesting, reduced impact logging (RIL) guidelines was developed in many countries, in various manners (Elias et al., 2001). In addition, environmental impact assessment (EIA), environmental performance indicators (EPI) and standards (ESI) for forest harvesting operations was improved with together ISO 14000 standards (Heinimann, 2007). As well, voluntary and compulsory practices such as best management practices (BMP) (Aust and Blinn, 2004) were developed for the forest operations.

Some assessment methods evaluating of the total environmental impact caused by wood harvesting lifetime started to be used. Life -Cycle Assessment (LCA) has become an effective tool to assess energy, material usages and releases to forest environment (Heinimann, 1999; Eker, 2016; Eker and Çoban, 2019). EIA, substance flow analysis (SFA), and sustainability impact assessment (SIA) are very utilizable methods for the analysis and assessment (Berg, 1995; Paivinen and Lindner, 2006).

However, as parallel to innovations on methods, equipment, and technologies used in harvesting operations, the paradigms about the forestry actions has changed. Heinimann (2007) explained the evolution by five paradigms on forest operations management that 
are: 1) Utilization paradigm, 2) Taylorizm paradigm, 3) Mechanization paradigm, 4) Systems paradigm, and 5) Network paradigm, as respectively. The changing paradigms are also the indicator of whether or not the environmental and humanistic considerations could be easily inserted to action at the real world.

It is necessary to evaluate the reflection of changing paradigms to forestry operations in conjunction with technology development. When the development of the technology level used in wood harvest operations in forestry is classified according to its historical course; it is known that basic technology until the 19th century, semi-mechanized intermediate technology in the 19-20th century, machine-advanced technology in the 20-21th century, and high technology with artificial intelligence and smart machines after the 21st century, have been used in the world forestry (Eker and Çoban, 2017). Furthermore, depending on the effects of developments at the technology level since 1950's related to the harvest operations, four different phases can be mentioned with futuristic trends, which are; (1) harvesting without touching the wood (chainsaw-based operations; no hand on the timber and foot on the forest ground), (2) harvesting without stepping on the forest ground (with harvest machines; no hand on the timber and no foot on the ground), (3) harvesting with unmanned and remote controlled vehicles (teleoperation with joysticks and/or haptic technology; no man in the machine and no hand on the handles), and (4) harvesting with smart machines and robots supported by artificial intelligence (unmanned systems) (Cavalli, 2015; Eker and Çoban, 2017).

\subsection{Forest Resources and Wood Harvesting Procedures}

According to the latest forestry inventory, the forest area occupies approximately 22.62 million hectares in Turkish Republic. The total growing stock is about 1.658 billion $\mathrm{m}^{3}$ and the total volume in annual increment is about 47 million $\mathrm{m}^{3}$. The annual allowable cut (AAC) is 18 - 20 million $\mathrm{m}^{3}$ or approximately 44 percent of the increment. It has been produced 19 million $\mathrm{m}^{3}$ round wood at the latest years (FS, 2020). At the current harvesting levels, it is estimated that $77 \%$ of domestic demand is met by sales of roundwood.

The General Directorate of Forestry (GDF) is the main institution in the sector, responsible for integration policy and supervision of the protection and sustainable forestry management, is part of the Ministry of Agriculture and Forestry (MAF). The majority (over 99\%) of forest land is state owned and managed by GDF. Forest harvesting decisions and operations have planned, organized, guided, managed, and controlled through the Chief Office of the Forest District (COFD), the Directorate of the Forest District (DFD), the Regional Directorate of Forestry (RDF), and also GDF (GDF, 2019), as respectively and hierarchically. It is exposed that the managerial process of harvesting decisions from COFDs to GDF has been executed by governmental legislations (hierarchical norms) the name of which is "Official Communique about Harvesting of Main Forest Products-No: 288 (until 2020) and Official Communique about Harvesting of Wood-based Forest ProductsNo:310 (in actual)" (GDF, 1996; GDF, 2020) (Figure 1).

The managerial process, which is a process about how the harvesting decisions are made for a forest compartment, starts in COFD level as budgetary preparation efforts and continues gradually forward by GDF. The each COFD prepare own proposal and it is reviewed at DFD, RFD and also GDF level before being submitted to MAF for further assessment. In this concept, a draft budget is reviewed at the budget commission depending on past performance and compliance with the strategic plan and objectives. Following this, once the budget is agreed then each COFD finalizes own program in line with the new budget. Thus, a COFD can decide to own harvesting capacity according as allocated budget. This cycle hierarchically has been sustained for whole forest administration in each year, from second half of preceding year to beginning of following year.

Wood harvest operations have been carried out by mostly forest villagers and rarely forest contractors. There is a legal obligation that the forest acts and regulations dictates that all forest works must be realized by forest villagers nearest to workplace. Forest workmanship provide vital economic contributions especially for forest villagers, which comprise of around 6.83 million people living over 22.847 forest villages (FS, 2020). They contribute to forest workmanship in care of Forest Villagers Cooperatives with 190.000300.000 members all around the country.

The operational process of forest harvesting comprises of tree main component that (1) cutting and felling, (2) extraction, and (3) hauling sub-process. Bucking, loading, and unloading takes place in the system dynamics, as well (Figure 2).

Cutting, delimbing, and bucking works (1) are realized in forest stand. Occasionally, debarking may be accomplished at the roadside. The chainsaw is used in cutting, delimbing and topping, bucking, and partly debarking by means of log wizard (Eker and Acar, 2006). Axe and delimber hand tool is mostly used in debarking. Nowadays, depending on sale type, debarking may be omitted from the harvesting system.

The extraction operations (2) from stump to landing or roadside is mostly (over $60 \%$ ) realized on the steep ground by means of gravity and human force as rolling, throwing, and sliding/skidding methods (Erdaş et al., 2014). Animal forced techniques are rarely used in recent and decreasing day by day. The use of agricultural tractors in harvest operations for logging has an uptrend (Şafak et al., 2019). The forest skylines, various distanced, have been used on mountainous region. 


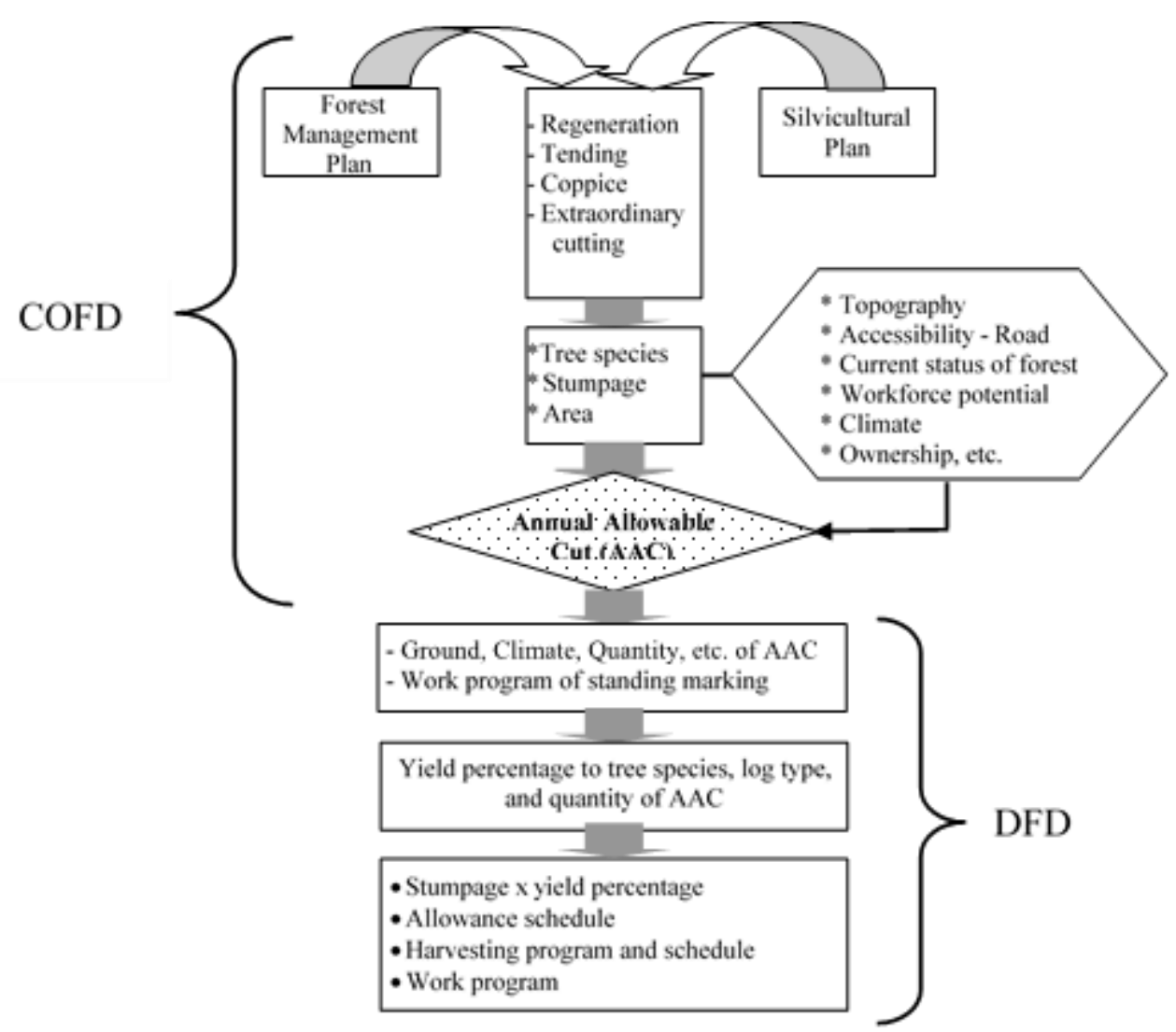

Figure 1. Work flowchart in managerial process of harvesting decisions (Eker,2004)

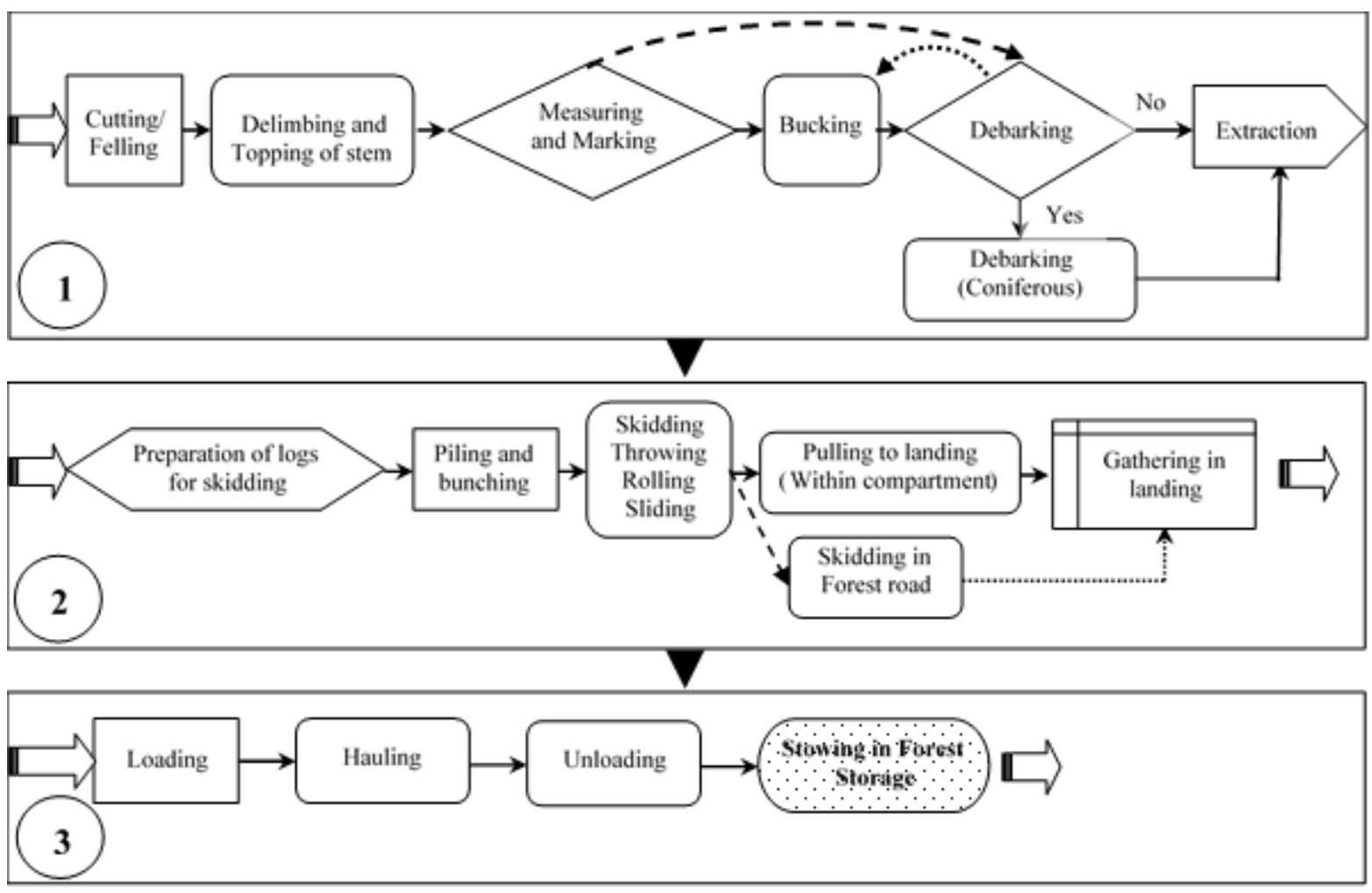

Figure 2. Work flowchart in operational process of wood harvesting (Eker, 2004)

Nowadays, the old cable yarders have been renewed because all of them had fulfilled the amortization lifetime. In addition, log chute system can be available for logging of small diameter wood products (Acar and Eroğlu, 2003). Heavy machines with advanced technologies such as harvesters, forwarders, and skidders are used in limited edition exception of few private forestry companies (Enez and Aricak 2012; Akay et al., 2016; Bilici et al., 2017). The preferred harvesting method is generally cut-to-length system. Loading operations in roadside or landing is carried out by using of grapple loaders or hydraulic cranes. Hauling (3) 
through forest roads and main roads is executed by trucks and trailer.

\section{Results and Discussion}

\subsection{Decisions at National Scale}

When the approaches to forests and forestry are taken into consideration, it is seen that developing and changing paradigms have been adopted in order to protect forest ecosystems and to benefit from resources in this framework, especially in developed and developing countries, within the scope of combating global climate change. In the worldwide, forestry sector, provides some strategic guidance to support sector goals, and defines opportunities for consideration in the sustainable development of the sector (Eker and Çoban, 2017). The strategies accept that the sustainable management of forest resources and nature protection are growing in importance as long-term challenges, along with climate change adaptation. In this respect, international forest policy is a part of global policy for sustainable development. The decisions of 2030 agenda for sustainable development aim to mitigate poverty, inequalities and climate change. Forest issues at global level are linked to the concerns such as global environmental change, indigenous people's rights and overall goals. Enhanced stakeholder role and a trend towards decentralization of decisions, there is an increasing shift from government to governance (World Bank, 2017).

At the same time, the truth has emerged that the national forest policy also needs to consider the global forest policy and international conventions, agreements and initiatives. The general principles, goals and policy in Turkey have been specified by the relevant ministries. The main policy documents are based on National Forestry Principles and the National Forestry Program (2004-2023), Forest Policy Note (2017-actual), the Eleventh Development Plan (2019-2023), and the General Directorate of Forestry's Strategic Plan (20192023) (GDF, 2019). For example, it is clearly seen that national forestry program has taken into consideration the principles such as sustainability, protecting biodiversity, multiple uses, participation, contribution to the development and stabilization of community (Alkan and Eker, 2005). As well, the GDF's strategic plan sets out the overall vision main objectives to protect the forests and biodiversity, to develop and expand the existing forests, increase their efficiency, to meet all expectations of the public, and to provide sustainable forest management. It can be said that these documents address numerous issues ranging from forest protection and ecosystem services to sustainable production of industrial wood and fuel wood to meet domestic demand. That is, national forestry goals, policies, and strategies have been structured according to the sustainability principles. Therefore, national level-decision making system should be well defined and this procedure should be compatible with international policies and approaches. In this respect, it is possible to say that environmental concerns of sustainable forestry are prioritized in the decisions making process.

In the background, it is seen that decisions regarding the protection of forests were taken in the constitution at the top of the hierarchy of norms. The constitution including some law article about forests and forestry, is a significant source of substantive forestry law. The Forest Law (6831 numbered), adopted in 1956, is wide ranging and addresses forest management and protection, forest improvement, and development of forest villagers as well (World Bank, 2017). However, it does not address the harvesting of or rights to forest products and lacks specific provisions around sustainable forest management. It can be stated that although the main forest legislation subject to many amendments, it suffers from a number of deficiencies including harvesting-based subjects. At the level of the constitution and laws, it can be considered that decisions have not been taken on issues related to the planning, guiding, management and supervision of wood harvest operations. The right thing is that the legislation on such matters may be searched in the lower steps of the hierarchy of norms. According to this, it is necessary to evaluate the communiqués (such as 288 and 310 numbered) containing the provisions of the chief executive for wood production.

On the other hand, as a general forest management strategy in Turkey; currently, decision makers aim to act within the multifunctional forestry approach (Odabaşı and Özalp, 1994). Considering various of forestry applications, the ones suitable for nature (continuous forest; forestry close to nature; forest suitable for ecological requirements) have been adopted. However, instead of narrow understanding of forestry (of biological origin), there is a tendency towards a comprehensive understanding of contemporary forestry.

Additionally, regarding the wood harvesting process; expansions for certification of systems, products and services for sustainable resource use has been also followed. At the end of 2019, a total of 9 million ha of forest has been certified to Forest Stewardship Council (FSC). The GDF plans to expand the area under certification to 10 million ha by the end of 2023 . There is no national forest standard for either FSC or the others. Within the certification of forestry operations, while there is awareness of the environmental impact of forest operations such as wood harvesting and also roading, there is no EIA requirement or best practice environmental guidance. However, it is well-known that it is aimed to develop national standard for certification in Turkey.

When examined the decision process relevant to protection, development, and utilization of forest resources, it was determined that national forestry goals of Turkish forestry were well-matched with global principles developed on sustainability of forest resources, in strategic level. Because, Turkey has agreed with UNCED and follow-up decision processes and 
applied criteria and indicators for providing of sustainability of forest management at national and regional scale. In tactical level, new multi-functional forest management planning approaches can serve to protect biodiversity and to provide other forestry functions and ecosystem services. Current management plans serve the balance of ecological, economic, social and cultural functions of forests subject to the understanding of ecosystem based functional planning. It is estimated and expected to be skillful of the management planning method to supply strategic environmental engagements. Thus, public interest may indirectly participate to harvesting decisions in tactical and also operational level.

As a general perception is that the decisions made at the strategic and tactical level are appropriate for protection, development, sustainable management of forest resources but there is a need to externalize the decisions into the harvest operations through workers/operators' attitudes.

\subsection{Decisions at Managerial and Operational Scale}

Managerial process is based on budget-balanced and there is a well-defined budget preparation process, which is technical and economical oriented and highly bureaucratic having long process beginning in the middle of the previous year of the plan year and ends at the beginning of the plan year. The budgetary affecting harvesting decision is centralized and has a ramified decision making. However, it can be declared that the business flow of forest harvesting is well-structured. The harvesting and work programs preparing in this process outline allowable harvesting quantity and budget. In point of operational efficiency view, the programs cannot describe how the harvesting operation is carried out, which harvesting system is used, how many worker is employed, etc. These are no having the quality of an operational harvest plan (Eker, 2004). Even though a work program is a part of a comprehensive plan, it does not carry out any plan characteristic only by itself (Öncer, 1991; Acar, 2001).

At the assignment stage of AAC, for the budget preparation a lot of variable such as accessibility, silvicultural prescription, germination time, workforce availability of forest villages, institutional expectations, even flow of forest products, forest storage stocks, etc. have been joined to decision process. However, it was not run into any wood logistics designs, planned in wood supply chain management context and depended on the philosophy of right time, right place and right products (Eker, 2005).

Public involvement has been taken into account to obtain AAC with regard to workforce potential of forest villagers. But, the harvesting decision process, both at COFD and GDF stages, is black-box. It was not provided the public participation to harvesting decision-making structure, yet. In recent years, some private actors, such as forest village cooperatives, forestry industry and non- governmental organizations, have become progressively participated into the forest sector and have a significant role in forest management activities. Nevertheless, it has been not taken into consideration any explicitly technical and economical precaution to assess and reduce of environmental impacts of harvest operations and their probable costs.

The general framework of wood harvest operations is indicated in Figure 2. At the work echelon of the operational process, delay and interchange may appear among the work phases according as initiative of forest workers and operators, harvesting technologies used in whole process, and work environment. This situation has affected to the operational efficiency of harvesting activities. Therefore, it is possible to explain that operational process of forest harvesting has a semistructured system. No evaluation criteria related to energy and material uses and waste disposal for the forest environment have been met.

Wood harvest operations have been carried out by mostly forest villagers. When the harvesting program is completed in budgetary process, COFD proposes which forest compartment is to be harvested and which forest villagers are employed for the harvesting operations. Then, the cutting, skidding, and hauling contracts are put in order between COFD and forest villagers or their cooperatives. There is no well-developed contracting infrastructure including current work practices, harvesting methods and systems (Özçelik, 2013). However, in the contracts, there is no any agreement on environmental friendly wood harvesting rules during operations and checklist including criteria EIA or EPI within control phase.

Currently, there is no official operational harvest planning approach focusing on selection of appropriate harvesting technology to sustain economical, environmental, and societal goals. During the harvest operations, no curative efforts are encountered that save time, reduce workload, increase efficiency and regulate the process during the operational process. The basic and intermediate technology (FAO, 1982) based on traditional harvesting methods has been preferred in current applications (Eker and Acar, 2006). There are no conspicuous governmental and professional rules to provide technical and economical improvements. On the other hand, in a scientific and experimental scale, the precision forestry (Kovacsova and Antalova, 2010; Eker and Özer, 2015) and small-scale forest operations (Akay, 2005) have been internalized for Turkish forestry as other developed forestry systems.

In addition, there is no inspection mechanism such as checklists about EIA, SFA, and LCA to assess the environmental impacts of harvesting operations. Life cycle analysis of harvesting processes (Eker and Önal, 2017) can be pathfinder to simply evaluate the relationship between technique, energy consumption, release, and cumulative impacts on work environment. However, it has been shown certain deficiencies on 
adapting and implementing of SFM principles for harvesting operations into site-specific level. The strategic and tactical decisions revealing in terms of forestry goals, principles, and policies has not been injected to operational process.

Intensively basic technologies and partially intermediate technologies were traditionally preferred in harvesting operations. Some reasons of the result are connected with; national policies requiring for rural development, low capital investment, terrain topography, machinery capacity of forest administrations, lack of qualified operators and workers, insufficiency of good quality forest road infrastructure, and etc. The main reasons focus on three factors of social, economic, and institutional.

Social factors: Forest villages are given preferential treatment under the Forest Law and have a right to employment in harvesting and all activities undertaken by GDF. They are key source of forestry employment and village's income is inextricably linked to the sustainability of forests. The harvesting operations carried out by forest villagers with cultural and educational differences whose main objectives are based on maximization of own annual income from forest employment. Despite this co-dependence-forests are playing a smaller role in the livelihoods of forest villagers (World Bank, 2017). This practice stands against the use of improved technology and greater efficiency, while having a strong social objective. Thus, operational efficiencies such as work productivity or time saving efforts are kept behind.

The forest villagers/workers are generally deprived of occupational training and education background. They are responsible for own safety and health, which are lack off social insurance. It is dictated to them that they should willingly fit to "Turkish Standards (TS-1214) on Tree Cutting and Safety Rules" in advisory manner by forest administration (GDF, 2020). Recently, GDF has given directions to local COFD that the forest workers should be adequately trained to be provided occupational safety and health. The GDF has operated a protocol with the Ministry of Education regarding training and all forest villages have received an eight-day training course on wood harvesting, safety and personal protection equipment (PPE). In the last 5 years, 100-120 thousand forest villagers have received safety and health training with the occupational manner and they have a certificate of tree cutting and bucking operator. Attendees have received a certificate on completion of the course which is seen as a transition stage to a qualified village workforce.

On the other hand, there is a shortcoming on development, implementation, and inspection of governmental rules and guidance about ESH and sufficient environmental concerns. In Turkey, although this is not a built-in level of guidance framework yet, at the operational scale, even developing a decision-making mechanism to address these issues and overcoming the human factor to the implementation of these decisions is a difficult task. As a matter of fact, in recent years, many forest workers/operators have been given technical and occupational health and safety trainings within the framework of national professional qualifications. Thus, it will be possible to provide people-oriented improvements in the near future in terms of enforcing the decisions taken at the upper and middle level decision processes. As with the approach developed by Alkan and Eker (2005) as the spinner model (Figure 3), the conversion of all kinds of objectives, policies and strategies and tactics related to forestry operation depends on the person living in the forest and working at the same time. Human beings are the practitioners as operator and worker of all technical, economic and environmental decisions in forest, stand, and tree scale. People's perception, expectation, attitude and behavior are a vital factor in this regard. However, people's employment and high income expectations show that they are ahead of environmental sensitivity.

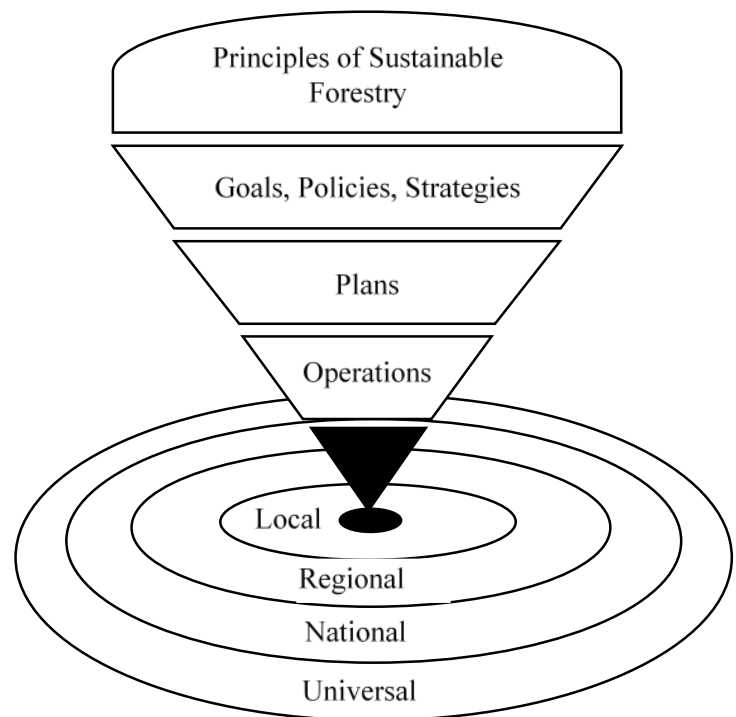

Figure 3. Decisions and their propagation in the forestry applications

Economic Factors: The production cost has been high because of the high labor cost, overheads, subsidies and harsh geographic conditions that increase skidding and transportation costs. Cuts for various funds are also another important factor that inflates production cost (FS, 2020). The economical effectiveness has been in the most important place to increase economic competitiveness by global markets. So, there are no endurances to cost addition for harvesting technologies protecting forest ecosystem and work environment.

In terms of loggers and workers, unemployment proportion has gradually increased in forest villages, so available work force is aging and labor cost and also gross national product ratio is decreasing. This means that there are a low machine investments and no mechanization. Therefore, forest harvesting operations has been realized by intensive manual methods. Because of the supporting of rural development endeavors is 
governmental policy, it cannot be abandoned to be employed of forest villagers in forest operations. Thus, social priorities preclude the operational productivity and environmental concerns. However, in recent years, with some public credit incentives, subventions from GDF, and increased purchasing power; it has become common for forest villagers to purchase agricultural tractors and use them in forestry. This will be a trigger to tend to mechanization in wood harvest operations. The new communiqué 310 numbered legislation supports using of agricultural tractors, as well.

Institutional factors: GDF is a large organization employing nearest 40,000 staff and is organized along classic forestry lines with a headquarters comprising service, supervisory and auxiliary units and from general to local (GDF, 2020). The GDF is a large centrally controlled organization that essentially sets its own targets and monitors itself. Although competitiveness in any organization is underpinned by having in place best practice, processes and procedures (World Bank, 2017); in the provincial organizations of GDF, there is no competition among forest enterprises based on technical, economic, and environmental criteria. Therefore, GDF needs to provide a more efficient and quality service to the forest sector as a whole with a range of financial, environmental, and social parameters. The analysis of decision process can provide insights as to where identifiable improvements can be made and lead to focused business process review of these aspects of how it does business (World Bank, 2017). It is difficult to make satisfactory decisions for all stakeholders, both in terms of management organization (administrative) and operating environment open to nature and society, since there are very complex system components concerning both organizational and operational decisions.

However, it can be claimed that there is already have several opportunities to insert the changing forestry paradigms and approaches to forestry practices. In the hierarchy of norms, new approaches human-oriented and operation-based can be developed while making decisions to remove deficiencies such as environmental subjects. Thus, Forest Policy should note that this would provide the opportunity to incorporate the principles of sustainable forestry covering whole ecosystems, social aspects, environmental and biodiversity values, impacts on climate change and risks of desertification (World Bank, 2017).

\section{Conclusions}

It is undeniable to ensure the sustainability of forests and of course the sustainability of utilization by applying the principles developed for the forestry sector at the universal scale and also at the national scale. Once these principles are incorporated into national forestry objectives, policies, and strategies, with tactical planning processes, they should also be inserted into decisions in the administrative and operational processes.
In Turkey, at the scale of forestry objectives, policies and strategies and hierarchy of norms (act, law, in and other legislation), it is possible to say that decisions are to be made environmental, economic, technical, socioeconomic, and intuitional level. However, it is understood that environmental and ergonomic issues cannot be sufficiently included in the decision making processes, especially in the budget balanced and technical weighted managerial process. Since an operational harvest planning is not made after management and silviculture plans, decisions based on multi-dimensional evaluation cannot be made, as well. As a result, the technical and economic axis procedure does not sufficiently contain environmental issues for planning, guiding, management, monitoring and controlling of forestry operations such as wood harvesting.

According to paradigms for forest operations management, forest harvesting operations are still at mechanization paradigm level. Therefore, it should be researched how to reach to the system and network paradigms to supply operational efficiency, environmental acceptability, and socio-economical viability in terms of voluntary and compulsory courses of action for governmental and professional rules.

As well, improvement of harvesting process in developing Turkish forestry requires followings; (1) process management engineering or short-distanced paper-work flow in a well-structured decision system manner, (2) strategies of wood supply chain management rules from stand to mill, (3) operational planning methodology based on information abstracted from ecological-based multifunctional forest management plans, (4) environmental performance criteria and indicators developed in global manner and evaluated by SFA and/or LCA methodology, (5) and developing or transferring appropriate harvesting technology that are economically and technically feasible, environmentally sensitive, institutionally and socially meet the ergonomic principles.

\section{References}

Acar, N., 2001. Production Planning Methods and Applications, MPM (National Productivity Centre) Publications No:280, 215 p., Ankara, Turkey.

Acar, H. H., Eroğlu, H., 2003. Extraction with Fiberglass Log Chute. Karadeniz Technical University, Report of Project No: 22.113.001-2, Trabzon, Turkey.

Akay, A.E., 2005. Using farm tractors in small-scale forest harvesting operations. Journal of Applied Sciences Research, 1(2): 196-199.

Akay, A.E., Özkan, D., Bilici, E., 2016. Assessing productivity and work safety of a mechanized logging operation. The International Forestry Symposium (IFS 2016). 7-11 December, Kastamonu, Turkey.

Alkan, H., Eker, M., 2005. A narrow view to the sustainability of utilizing forest resources. Proceedings of Chamber of Forest Engineers 
Symposium, 22-24 December, Antalya, Turkey. pp: 423-437.

Aust, W. M., Blinn, C. R., 2004. Forestry best management practices for timber harvesting and site preparation in the Eastern United States: An overview of water quality and productivity research during the past 20 years (1982-2002). Water, Air, and Soil Pollution: Focus, 4: 5-36.

Berg, S., 1995. The environmental load of fossil fuels in Swedish forestry-an inventory for a LCA. Life-Cycle Analysis-a Challenge for Forestry and Forest Industry, EFI Proceedings (Ed. by Frühwald and Solberg, B.) No:8, 57-65.

Bilici, E., Akay, A.E., Abbas, D., 2017. An evaluation of a fully mechanized forest harvesting operation in Bursa, Turkey. ISFOR 2017 International Symposium on New Horizons in Forestry. 18-20 October, Isparta, Turkey.

Cavalli, R., 2015. Forest operations in steep terrain. Forest Engineering Conference - CROJFE 2015, 18 20 March 2015, Zagreb, Croatia.

Dykstra, D.P. and Heinrich, R., 1996. FAO Model Code of Forest Harvesting Practice. FAO Publications, 85 p., Rome, Italy.

Eker, M., 2004. Development of Annual Operational Planning Model for Timber Harvesting. PhD Thesis, Karadeniz Technical University, Trabzon, Turkey. $239 \mathrm{p}$.

Eker, M., Acar, H.H., 2004. A review on the log wizard using in terms of forest workmanship, X. Ergonomic Congress, Uluda $\breve{g}$ University, 08-10 October, Bursa, Turkey.

Eker, M., 2005. A Research on the Logistics Design for Turkish Wood Supply Chain Management. Individual Research Project with Tunca, M.Z., Sütçü, A., Alkan, H., Uysal, S., SDÜ-APYB-Project No: 1087-m-05, Süleyman Demirel University, Isparta, Turkey.

Eker, M., Acar, H.H., 2006. Operational Planning in Wood Harvesting. SDU-Faculty of Forestry Journal, A(2): 128-140

Eker, M., Özer, D., 2015. Precision forestry in forest harvesting: Conceptual framework. Turkish Journal of Forestry, 16(2):183-194.

Eker, M., 2016. Life cycle inventory in wood harvesting for sensitive forest operations. 1st International Symposium of Forest Engineering and TechnologiesFETEC 2016, 2-4 June, Bursa, Turkey. Book of Abstracts, p. 31.

Eker, M., Çoban, H.O., 2017. Forestry operations in the context of changing paradigms and developing technology. IV. National Forestry Congress, The Foresters' Association of Turkey, 15-16 November, Antalya, Turkey.

Eker, M., Önal, Y.E., 2017. Life cycle assessment for wood harvesting in Turkish forestry conditions. Proceedings of International Symposium on New
Horizons in Forestry, 18-20 October, Isparta, Turkey. p. 431.

Eker, M., Çoban, H.O., 2019. The relationship between forest operations and climate change. Proceedings of the Conference on Climate Change and Forestry. 1314 Nov., Antalya, pp: 260-268.

Elias, G. A., Kartawinata, K.M., Klassen, A., 2001. Reduced Impact Logging Guidelines for Indonesia, CIFOR, Bogor-Indonesia.

Enez, K., Arıcak, B., 2012. Evaluation of the technical and working conditions of the tree harvester, $K S U J$. Engineering Sci., Special Issue, I: 108-114.

Erdaş, O., Acar, H.H., Eker, M., 2014. Transportation Techniques for Forest Products. Karadeniz Technical University, Faculty of Forestry, No:233/39, Trabzon, Turkey. p. 504.

FAO, 1982. Basic Technology in Forest Operation, FAO Forestry Paper No: 31, Rome, Italy.

FS,2020. Forestry Statistics, Official Statistics, General Directorate of Forestry. https://www.ogm.gov.tr/ekutuphane/Sayfalar/Istatist ikler. Accessed: 10 April 2020.

Türker, A., Geray, A. U., Yılmaz, E., 2001. A different approach to functional (functional) planning Forest Engineering Journal, 38(3): 19-23, Ankara, Turkey.

GDF, 1996. Official Inspection about Harvesting of Main Forest Products-No.288. General Directorate of Forestry, Ankara, Turkey.

GDF, 2019. Strategic Plan (2019-2023) of General Directorate of Forestry. Ministry of Agriculture and Forestry. Ankara, Turkey. https://www.ogm.gov.tr/ekutuphane/StratejikPlan/

GDF, 2020. Official Communique about Harvesting of Wood-based Forest Products - No:310. General Directorate of Forestry, Ankara, Turkey. https://www.ogm.gov.tr/ekutuphane/Tebligler

Accessed: 13 February 2020.

Heinimann, H.R., 1999. Forest Operations Under Mountainous Conditions, Forests in Sustainable Development, Oregon State University, Corvallis, OR, USA. 7p.

Heinimann, R.H., 2007. Forest operations engineering and management, the ways behind and ahead of scientific discipline. Croatian Journal of Forest Engineering, 28 (1): 107-121.

IFC, 2007. Environmental, Health, and Safety Guidelines - Forest Harvesting Operations. International Finance Corporation World Bank Group, April 30, 21 p.

ILO, 1998. Safety and Health in Forestry Work: An ILO Code of Practice. ILO, Geneva, $166 \mathrm{p}$.

IUFRO, 2017. Scientific Divisions, Division 3 - Forest Operations Engineering and Management. https://www.iufro.org/science/divisions/division-3/ Access:15 July 2017.

Kovacsova, P., Antalova, M, 2010. Precision forestry definition and technologies. Šumarski list br. 11-12, CXXXIV (2010): 603-611. 
Odabaşı, T., Özalp, G., 1994. Operation methods of forests and understanding of forestry suitable for nature. Istanbul University Faculty of Forestry Journal - B, 44(1-2):35-47.

Öncer, M., 1991. Production Planning and Control in Forest Product Industry. MPM Publication No: 443, $72 p$.

Özçelik, K., 2013. Investigation of decision-making process on harvest operations in the context of environmentally sensitive forestry. MSc. thesis, Süleyman Demirel University, Isparta, Turkey.
Paivinen, R. and Lindner, M., 2006. Assessment Sustainability of Forest Wood-Chains. EFI Technical Report-23, European Forest Institute, 13 p.

Şafak, İ., Eker, M., Erdem, M., Turan, İ., 2019. Time and motion analysis on cable skidding with agricultural tractors of coniferous logs. Turkish Journal of Forestry Research, 6(1): 58-47.

World Bank, 2017. Forest Policy Note-TURKEY, World Bank Group, 112 p. 